\title{
NIERÓWNOŚCI W ZDROWIU W ŚWIETLE WYNIKÓW PROJEKTU „PROBLEM ZGLASZALNOŚCI KOBIET NA BADANIA CYTOLOGICZNE W POLSCE. PRÓBA ANALIZY SOCJOMEDYCZNEJ"
}

\begin{abstract}
Abstrakt. Niska zgłaszalność kobiet na bezpłatne badania cytologiczne oferowane w ramach Populacyjnego Programu Profilaktyki i Wczesnego Wykrywania Raka Szyjki Macicy (PPPWWRSM) stanowi zagadnienie wymagające pogłębionej analizy. Przedstawiony projekt jest jednym z pierwszych reprezentatywnych badań socjologicznych, dotyczących tej problematyki. Głównym celem projektu były opis oraz interpretacja postaw kobiet wobec profilaktycznych badań cytologicznych, a także diagnoza przyczyn unikania/odkładania w czasie takich badań.

Z uwagi na złożoność przedmiotu badań, zastosowano dwa rodzaje analizy: jakościową i ilościową. Przeprowadzono 80 wywiadów swobodnych, z których wnioski wykorzystano na etapie przygotowania narzędzia do badań o charakterze ilościowym. Wywiady bezpośrednie (CAPI) zostały zrealizowane jesienią 2014 r. na ogólnopolskiej reprezentatywnej próbie 500 kobiet w wieku 25-59 lat (populacja objęta PPPWWRSM).

Efektem badań jest wiedza dotycząca zachowań zdrowotnych Polek oraz ich społecznych uwarunkowań. Na szczególną uwagę zasługują odmienne wzorce postępowania, wynikające ze
\end{abstract}

* Dr hab., prof. UMCS, Samodzielna Pracownia Socjologii Medycyny, Katedra Nauk Humanistycznych, Wydział Nauk o Zdrowiu, Uniwersytet Medyczny w Lublinie, ul. Staszica 4/6, 20-059 Lublin; Zakład Socjologii Medycyny i Rodziny, Instytut Socjologii, Wydział Filozofii i Socjologii, Uniwersytet Marii Curie-Skłodowskiej, pl. Marii Curie-Skłodowskiej 4, 20-031 Lublin; e-mail: wlodzimierz.piatkowski@umlub.pl.

${ }^{* *}$ Mgr, Zakład Socjologii Medycyny i Rodziny, Instytut Socjologii, Wydział Filozofii i Socjologii, Uniwersytet Marii Curie-Skłodowskiej, pl. Marii Curie-Skłodowskiej 4, 20-031 Lublin; Samodzielna Pracownia Socjologii Medycyny, Katedra Nauk Humanistycznych, Wydział Nauk o Zdrowiu, Uniwersytet Medyczny w Lublinie, ul. Staszica 4/6, 20-059 Lublin; e-mail: a.h.sadowska@, gmail.com.

*** Dr n. med., I Katedra i Klinika Ginekologii Onkologicznej i Ginekologii, I Wydział Lekarski, Uniwersytet Medyczny w Lublinie, ul. Staszica 16, 20-081 Lublin; e-mail: m.s.bobinski@, gmail.com.

**** Prof. dr hab. n. med., I Katedra i Klinika Ginekologii Onkologicznej i Ginekologii, I Wydział Lekarski, Uniwersytet Medyczny w Lublinie, ul. Staszica 16, 20-081 Lublin; e-mail: wbed@wp.pl. 
zróżnicowania społeczno-kulturowego (m.in. wiek, miejsce zamieszkania, wykształcenie), przejawiające się w korzystaniu z opieki ginekologicznej, wiedzy na temat profilaktyki i jej źródeł oraz motywacji do podejmowania aktywności prozdrowotnej ${ }^{1}$.

Słowa kluczowe: nierówności społeczne, profilaktyka ginekologiczna, socjologia medycyny.

\section{Wstęp}

W klasycznej zachodniej socjologii medycyny „zagadnienia zdrowia kobiet” pojawiły się w literaturze przedmiotu na przełomie lat 60. i 70. XX w., jednak opisy tych problemów mają swoją dłuższą historię. Emily Mumford, charakteryzując ewolucję poglądów na ten temat w konserwatywnych stanach USA w połowie XIX w., przytacza opinię przypisywaną prezydentowi Towarzystwa Ginekologicznego z Massachusetts: „I never found it necessary to uncover a patient for a gynecological examination" (Mu m ford 1983: 280). Cytowana autorka zwraca uwagę, że jeszcze do końca wieku XIX większość lekarzy wykazywała się małą znajomością kobiecej fizjologii. Równocześnie w ostatnich dekadach tego wieku powstawało w Stanach Zjednoczonych szereg stowarzyszeń (np. The Ladies Physiological Institute of Boston) mających na celu propagowanie wśród pań z ówczesnych klas wyższych elementów profilaktyki zdrowotnej (Mumford 1983: 280). Ewolucja „filozofii” ówczesnej ginekologii przebiegała od aprobaty dla „mechanistycznych” podejść do kobiecego ciała (obiektu leczenia) do stopniowo przyjętego poglądu, zakładającego traktowanie kobiety-pacjenta jako osoby z pełnią przysługujących jej praw do godności oraz zachowania intymności.

W latach 70. i 80. XX w. wśród analiz sytuacji zdrowotnej kobiet w krajach rozwiniętych pojawiło się szereg prac prezentujących tzw. ,podejście krytyczne" (critical perspective) i odnoszących się do niższego statusu socjoekonomicznego tej kategorii osób, co miało m.in. skutkować ich mniejszym dostępem do wysokospecjalistycznych usług zdrowotnych, zaawansowanej diagnostyki czy drogich procedur terapeutycznych. Zwracano uwagę, że np. w USA zjawisko to dotyczyło kobiet o niskim poziomie wykształcenia, niewysokich dochodach, wywodzących się z rodzin latynoskich czy afroamerykańskich (E s t e s, Li in k i n s 2000: 154). Równocześnie w tym samym okresie sondażowe badania socjologiczne pokazywały stopniową feminizację amerykańskiej medycyny: poczynając od zawodu lekarza rodzinnego, poprzez pediatrię i ginekologię, a skończywszy na neurochirurgii (C o c ker h a m 2004: 196).

Społeczny i kulturowy kontekst profilaktyki ginekologicznej współcześnie wyznacza też problematyka ,socjologii ciała” (sociology of the body), podkreślająca znaczenie rozumienia cielesności jako efektu oddziaływania stosunków i sytuacji społecznych, wpływu religii, etyki, stereotypów cywilizacyjnych oraz sposobu socjalizacji w podstawowej grupie społecznej, jaką jest rodzina. Pośrednio

\footnotetext{
${ }^{1}$ Projekt został sfinansowany ze środków Narodowego Centrum Nauki przyznanych na podstawie decyzji numer DEC-2011/03/B/HS6/04503.
} 
lub bezpośrednio upowszechnianie tego typu wiedzy przez mass media, kulturę masową i ruchy feministyczne spowodowało, że kobiety inaczej, pełniej i głębiej zaczęły pojmować własne ciało i jego anatomiczną i fizjologiczną tożsamość, zaczęły poprawnie interpretować sygnały z niego płynące, pragnęły nie tylko inwestować we własną cielesność w kontekście zdrowia i choroby, ale też ją planować i kreować (N e t tl e t o n 2009: 129-134).

Rosnącą rolę na obszarze wyznaczonym przez pojęcia: zdrowie kobiet - profilaktyka - choroby nowotworowe zaczyna także odgrywać radykalny feminizm. Działaczki tego ruchu zwracają uwagę na fakt, że w wielu krajach zachodnich dochodzi do postępującego zróżnicowania socjoekonomicznego społeczeństw (Grecja, Hiszpania, Portugalia, USA), a efektem tych rosnących i kumulujących się różnic jest marginalizacja, segregacja i dyskryminacja (także zdrowotna) części kobiet wywodzących się z grup nielegalnych imigrantów, uchodźców politycznych, osób nieposiadających prawa legalnego pobytu i bez ubezpieczenia medycznego. Feministyczna krytyka promocji zdrowia bada, opisuje i interpretuje zjawiska wykluczenia i ograniczenia dostępu kobiet $\mathrm{z}$ wymienionych grup do badań profilaktycznych i kontrolnych również na obszarze prewencji ginekologicznej (D a y kin, Naid o o 2005: 59-60).

\section{Uzasadnienie podjęcia badań nad profilaktyką cytologiczną w Polsce}

Badania Autorów nad niską zgłaszalnością Polek na badania cytologiczne szyjki macicy zainspirowała niepełna znajomość rzeczywistych wskaźników korzystania/niekorzystania z tego typu badań oraz niedostatki systemu raportowania i sprawozdawczości - obejmującego jedynie Populacyjny Program Profilaktyki $i$ Wczesnego Wykrywania Raka Szyjki Macicy (PPPiWWRSM), bez uwzględnienia sektora niepublicznego oraz świadczeń publicznych, wykonywanych poza tym programem. Inny problem stanowily istotne rozbieżności pomiędzy oczekiwanymi i realnymi efektami realizacji programów dotyczących profilaktyki ginekologicznej w Polsce. Podjęcie badań wynikało także z braku systematycznych polskich publikacji, uwzględniających zmienne socjomedyczne (łączących analizy o charakterze ilościowym i jakościowym) oraz brak kompleksowych i interdyscyplinarnych analiz zjawiska na obszarze medycyny klinicznej, medycyny społecznej i epidemiologii.

\section{Material i metody badań własnych}

Projekt „Problem zgłaszalności kobiet na badania cytologiczne w Polsce. Próba analizy socjomedycznej” został sfinansowany ze środków Narodowego Centrum Nauki. Badania realizowano w latach 2012-2015, w dwóch etapach. 
W pierwszym z nich przeprowadzono 80 wywiadów swobodnych z kobietami hospitalizowanymi z rozpoznaniem choroby nowotworowej szyjki macicy lub zgłaszającymi się do poradni w celu wykonania profilaktycznego badania cytologicznego. Analiza transkrypcji pozwoliła na wyłonienie pierwszych hipotez, stanowiących istotne wskazówki w przygotowaniu kwestionariusza do wywiadów bezpośrednich wspomaganych komputerowo (CAPI). Badania o charakterze ilościowym zostały zrealizowane na zlecenie zespołu autorów projektu przez TNS Polska jesienią 2014 r. na reprezentatywnej próbie 500 Polek w wieku 25-59 lat, co odpowiada populacji objętej PPPiWWRSM. Próba miała charakter losowo-kwotowy. W analizie statystycznej wykorzystano test chi-kwadrat, za poziom istotności przyjmując $\mathrm{p}<0,05$.

\section{Nierówności w zdrowiu na przykladzie profilaktyki cytologicznej - wyniki projektu}

Jednym z najistotniejszych aspektów analizowanych zachowań zdrowotnych związanych z profilaktyką ginekologiczną jest częstotliwość wizyt u lekarza ginekologa (ryc. 1). Łącznie ponad połowa respondentek deklarowała, że odbywa taką wizytę raz w roku (38\%) lub częściej (16\%). Aż 17\% badanej populacji odwiedza ginekologa rzadziej niż co 3 lata.

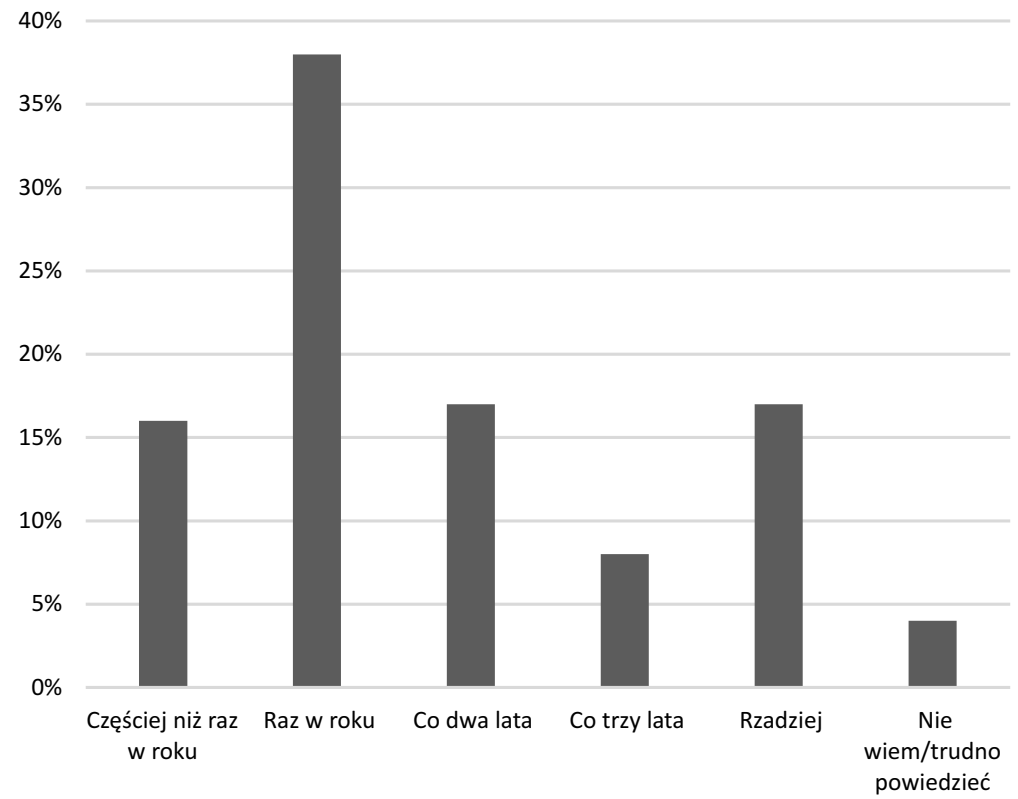

Ryc. 1. Częstotliwość wizyt u lekarza ginekologa wśród badanych kobiet $(\mathrm{N}=499)$ Źr ódło: Wyniki projektu 
Częstotliwość wizyt ginekologicznych pozostaje w istotnym statystycznie związku z miejscem zamieszkania (test chi-kwadrat: 43,$22 ; \mathrm{p}=0,002$ ), wiekiem (test chi-kwadrat: 38,$74 ; p=0,001$ ) oraz poziomem wykształcenia respondentek (test chi-kwadrat: 34,$15 ; \mathrm{p}=0,000)$. Kobiety zamieszkujące w większych ośrodkach, w młodszych grupach wiekowych (w szczególności pomiędzy 30. i 39. rokiem życia), o wyższym poziomie wykształcenia zdecydowanie częściej regularnie korzystają z badań ginekologicznych. Zaobserwowane zależności zostały przedstawione na ryc. $2-4$.

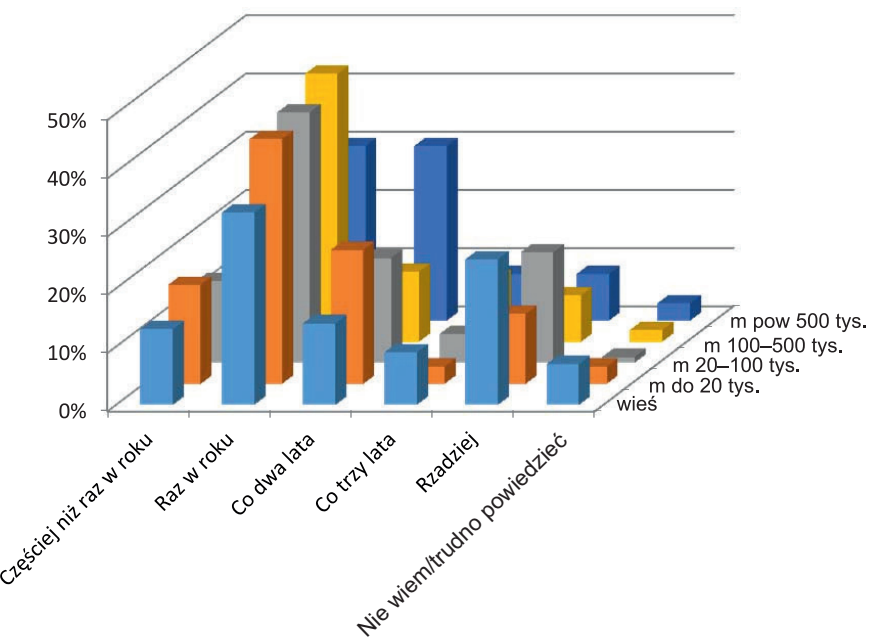

Ryc. 2. Częstotliwość wizyt u lekarza ginekologa w zależności od miejsca zamieszkania badanych kobiet Źródło: Wyniki projektu

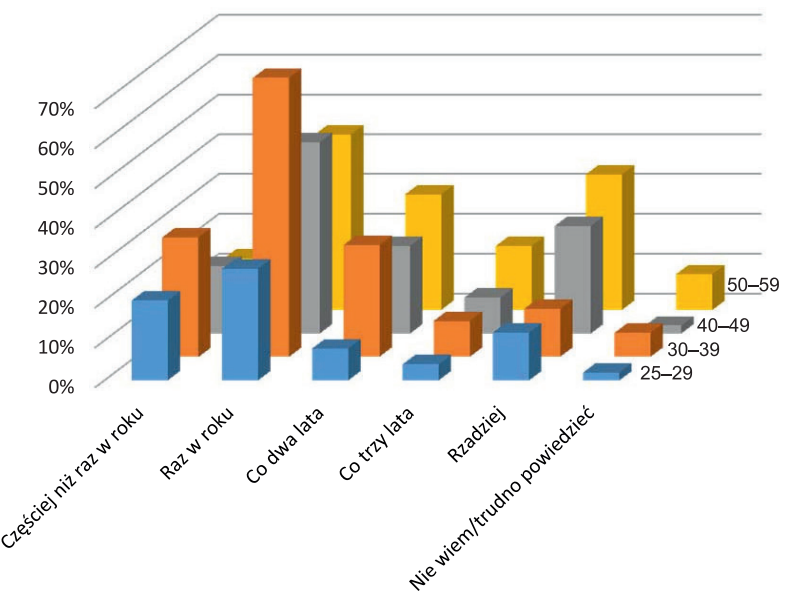

Ryc. 3. Częstotliwość wizyt u lekarza ginekologa w zależności od wieku badanych kobiet Źr ódło: Wyniki projektu 


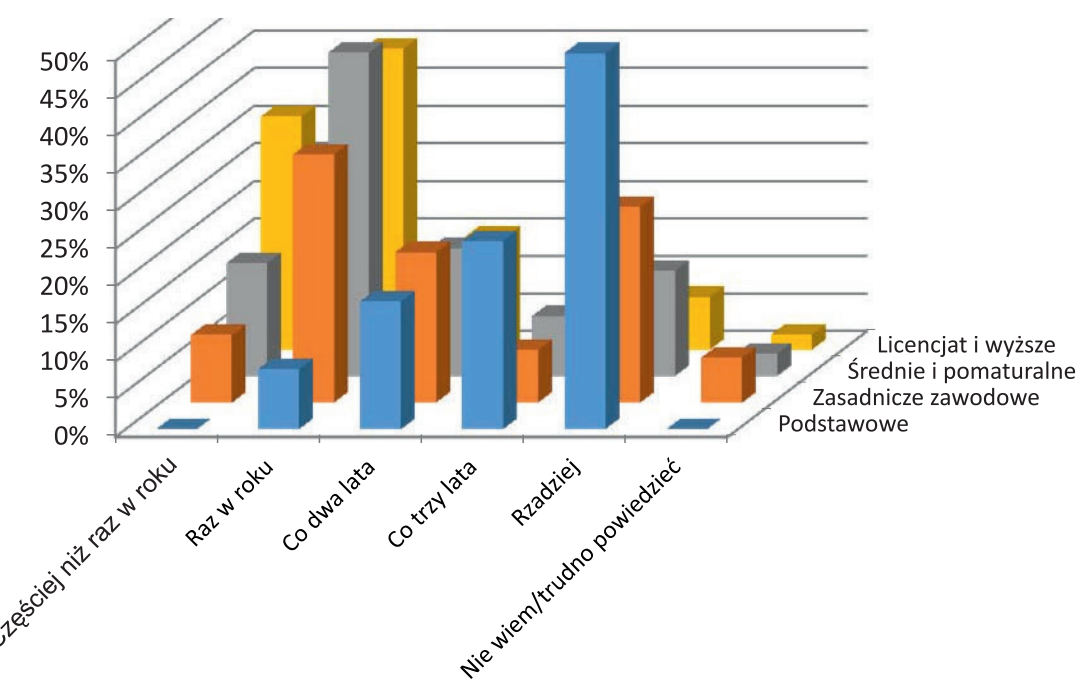

Ryc. 4. Częstotliwość wizyt u lekarza ginekologa w zależności od poziomu wykształcenia badanych kobiet

Źr ódło: Wyniki projektu

W tym kontekście warto zauważyć, że 26\% respondentek deklarowało dostęp do prywatnej opieki zdrowotnej. Zdecydowana większość z tej grupy korzysta tylko i wyłącznie z prywatnych usług ginekologicznych, $68 \%$ - z usług Narodowego Funduszu Zdrowia, zaś 4\% - z oferty obu systemów. Zdecydowanie częściej z prywatnych usług ginekologicznych korzystają kobiety przed 50. rokiem życia (wśród kobiet w wieku 25-29 lat - 27\%, 30-39 lat - 28\%, 40-49 lat-24\%; wśród pań w wieku 50-59 lat-12\%).

Innym aspektem postaw wobec zdrowia, uwzględnionym w badaniu, była wiedza na temat badania cytologicznego. Wśród ankietowanych zdecydowana większość (98\%) słyszała o badaniach cytologicznych, a 86\% zadeklarowało, że wie, na czym polega cytologia. Do niewiedzy, częściej niż ogół, przyznawały się mieszkanki wsi, osoby gorzej wykształcone, ale również te w najstarszej grupie wiekowej.

Na pytanie o prawidłową częstotliwość przeprowadzania profilaktycznego badania cytologicznego nieco ponad połowa respondentek (51\%) wskazała na odpowiedź „raz do roku”, 24\% - „raz na dwa lata”, zaś 9\% - „raz na pół roku”. Tylko $7 \%$ ankietowanych uważa, że badanie cytologiczne powinno być przeprowadzone rzadziej niż co 2 lata, a 10\% przyznało, że nie zna prawidłowej odpowiedzi (ryc. 5).

Podobnie jak w przypadku pytań o częstotliwość wizyt u lekarza ginekologa, również w przypadku pytań o wiedzę na temat prawidłowej/zalecanej częstotliwości badań cytologicznych wykazano statystycznie istotną zależność ze zmiennymi: miejsce zamieszkania (test chi-kwadrat: 35,$401 ; \mathrm{p}=0,004)$ i poziom wykształcenia (test chi-kwadrat: 16,184; $\mathrm{p}=0,003$ ). 
$60 \%$

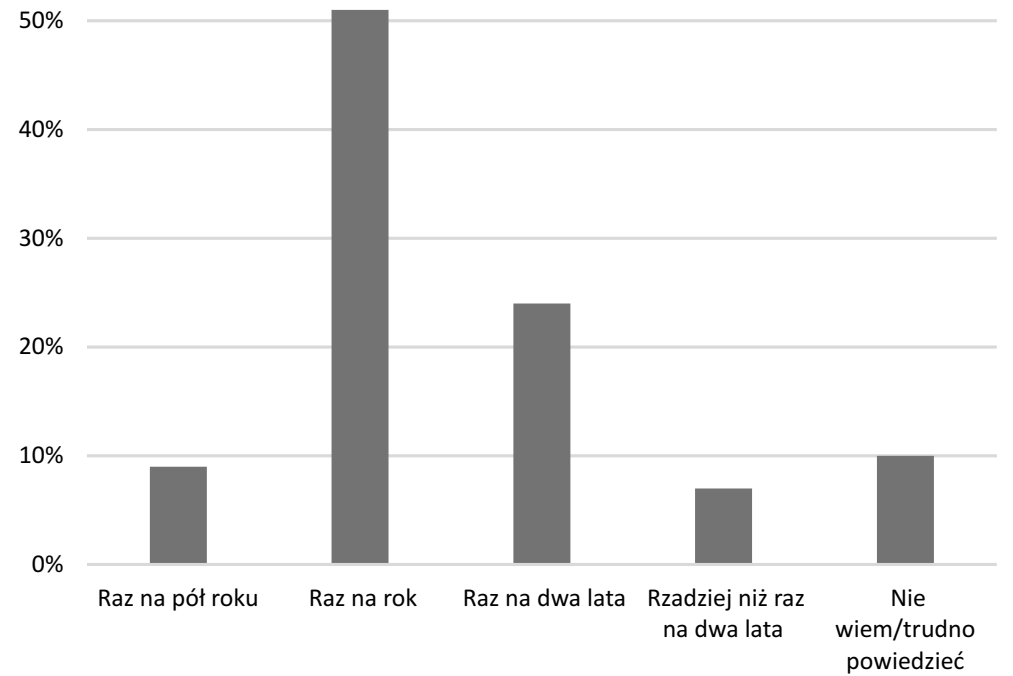

Ryc. 5. Prawidłowa częstotliwość przeprowadzania badań cytologicznych według badanych kobiet $(\mathrm{N}=491)$

Źr ódło: Wyniki projektu

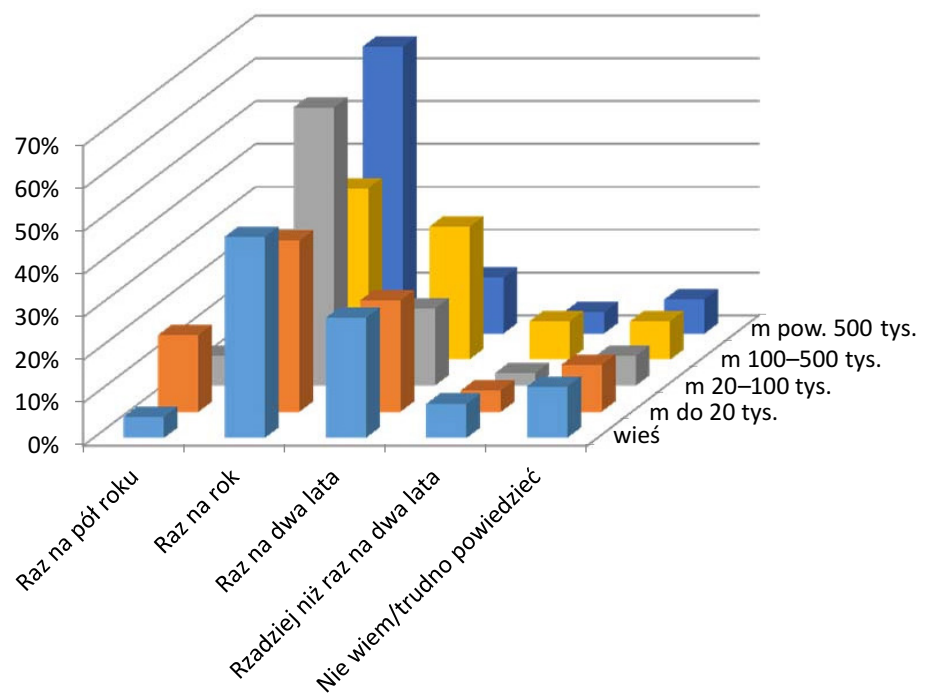

Ryc. 6. Prawidłowa częstotliwość przeprowadzania badań cytologicznych według badanych kobiet w zależności od miejsca zamieszkania 


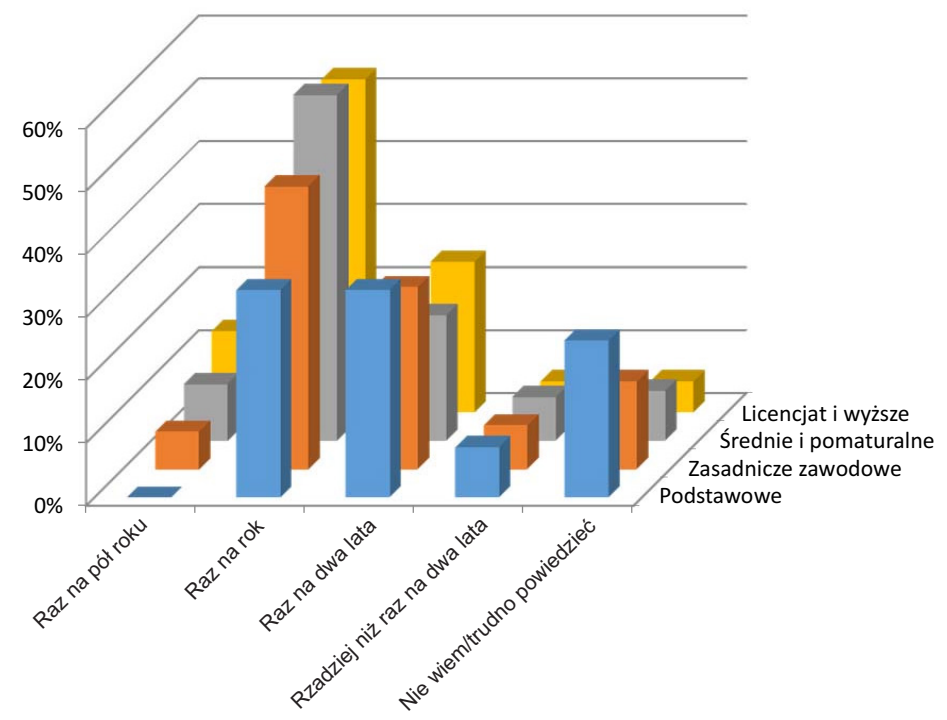

Ryc. 7. Prawidłowa częstotliwość przeprowadzania badań cytologicznych według badanych kobiet w zależności od poziomu wykształcenia

\section{Źródło: Wyniki projektu}

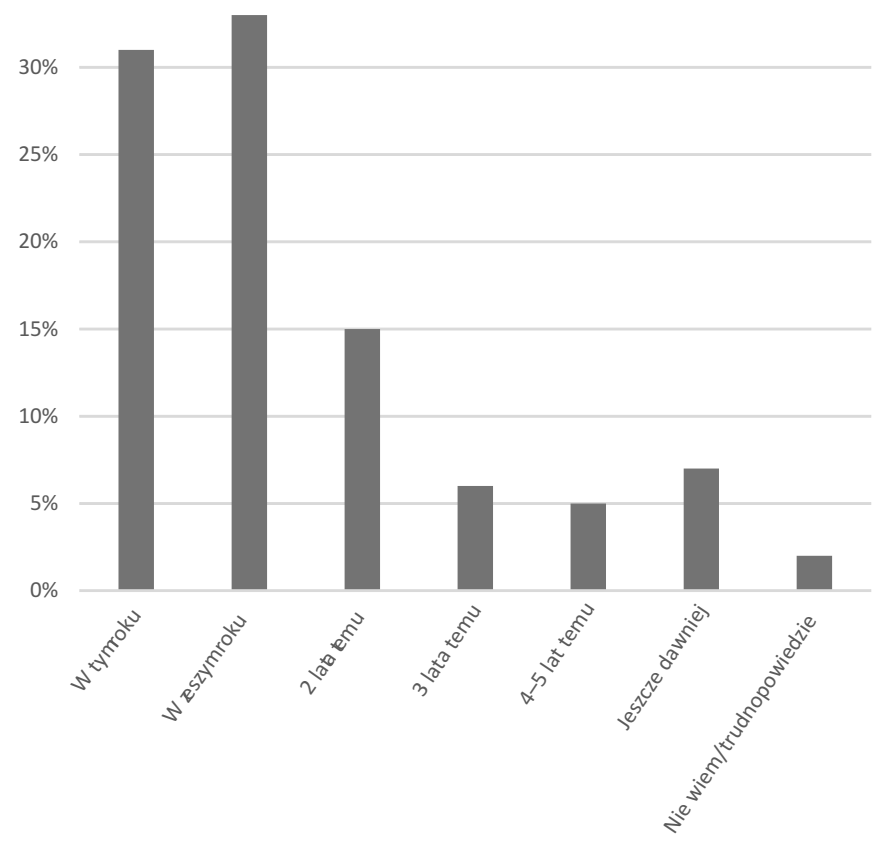

Ryc. 8. Czas wykonania ostatniego badania cytologicznego $(\mathrm{N}=452)$ 
Na ryc. 8 przedstawiono rozkład odpowiedzi na pytanie o czas, w którym respondentki poddały się ostatniemu badaniu cytologicznemu. Optymistyczny jest fakt, że aż $64 \%$ respondentek wykonało takie badanie w roku bieżącym lub poprzedzającym wywiad, a 15\% - 2 lata wcześniej. Niestety, aż 18\% respondentek (łącznie) poddawało się badaniu 3 lata temu bądź dawniej. Ponownie zmienną niezależną jest $\mathrm{w}$ tym przypadku wykształcenie (test chi-kwadrat: $19,465 ; \mathrm{p}=0,003)($ ryc. 9).

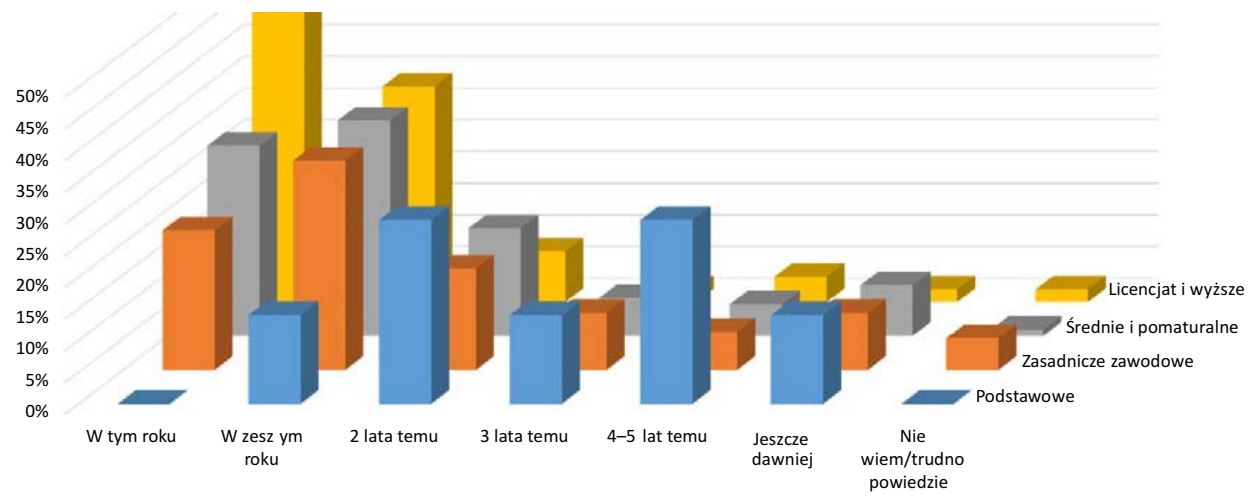

Ryc. 9. Czas wykonania ostatniego badania cytologicznego w zależności od poziomu wykształcenia badanych kobiet

Źr ódło: Wyniki projektu

Wśród czynników, które skłoniły ankietowane do przeprowadzenia profilaktycznych badań cytologicznych dominowały: sugestia lekarza ginekologa (43\%) oraz motywacja własna (aż 39\%). Zachęta ze strony lekarza rodzinnego/ innego pracownika służby zdrowia stanowiły tylko odpowiednio: 9 i 5\%. Oddziaływanie rodziny oraz imienne zaproszenia na bezpłatne badania (po 9\%) okazały się w równym stopniu motywujące, natomiast wskazania związane z bieżącymi dolegliwościami bądź ciążą skłaniały do badań cytologicznych na poziomie 10 i $7 \%$ (ryc. 10).

Wśród badanych kobiet 38\% przyznało, że co najmniej raz w życiu otrzymały imienne zaproszenie na bezpłatne badania cytologiczne. Mimo, że imienne zaproszenia uznano za najskuteczniejszą formę informowania o bezpłatnych badaniach cytologicznych (41\%), jedynie 6\% respondentek wskazywało ten sposób jako skuteczną formę zachęcania/przekonywania do profilaktyki raka szyjki macicy. Ma to odzwierciedlenie w stopniu realizacji otrzymanych zaproszeń: 39\% ankietowanych przyznało, że nie zgłosiły się na proponowane badanie cytologiczne (ryc. 11). 


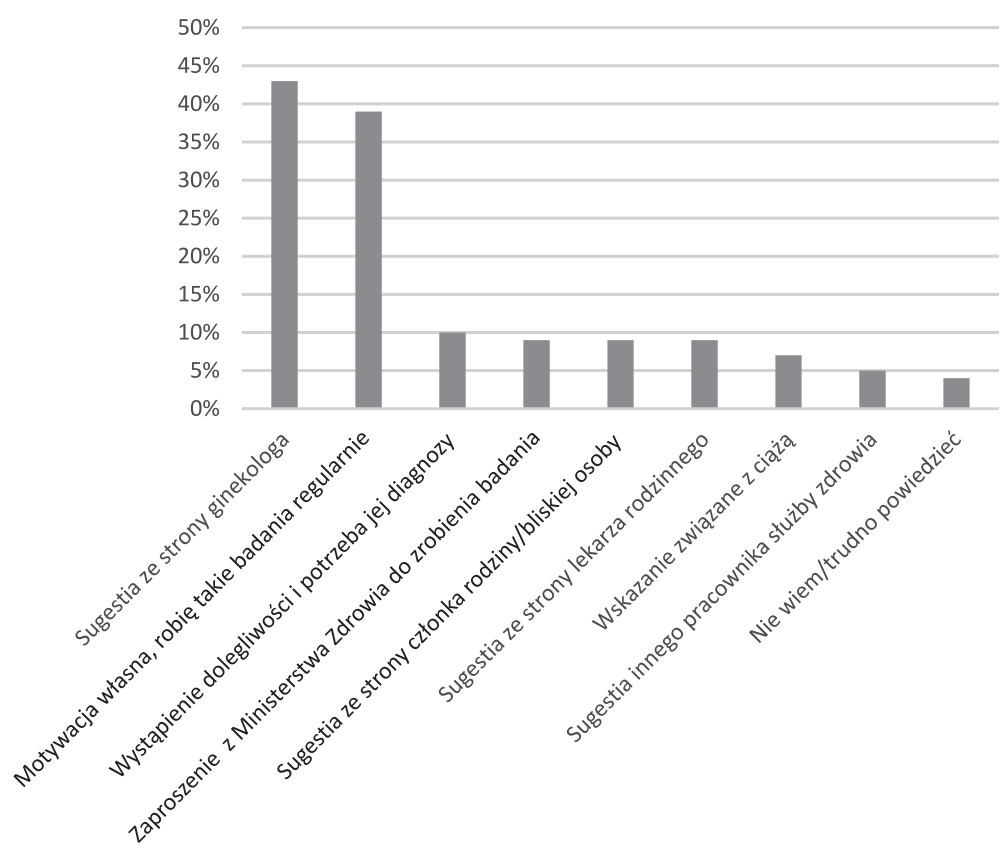

Ryc. 10. Czynniki skłaniające do przeprowadzenia badania cytologicznego w opinii badanych kobiet $(\mathrm{N}=452, \max .3)$

Źr ódło: Wyniki projektu

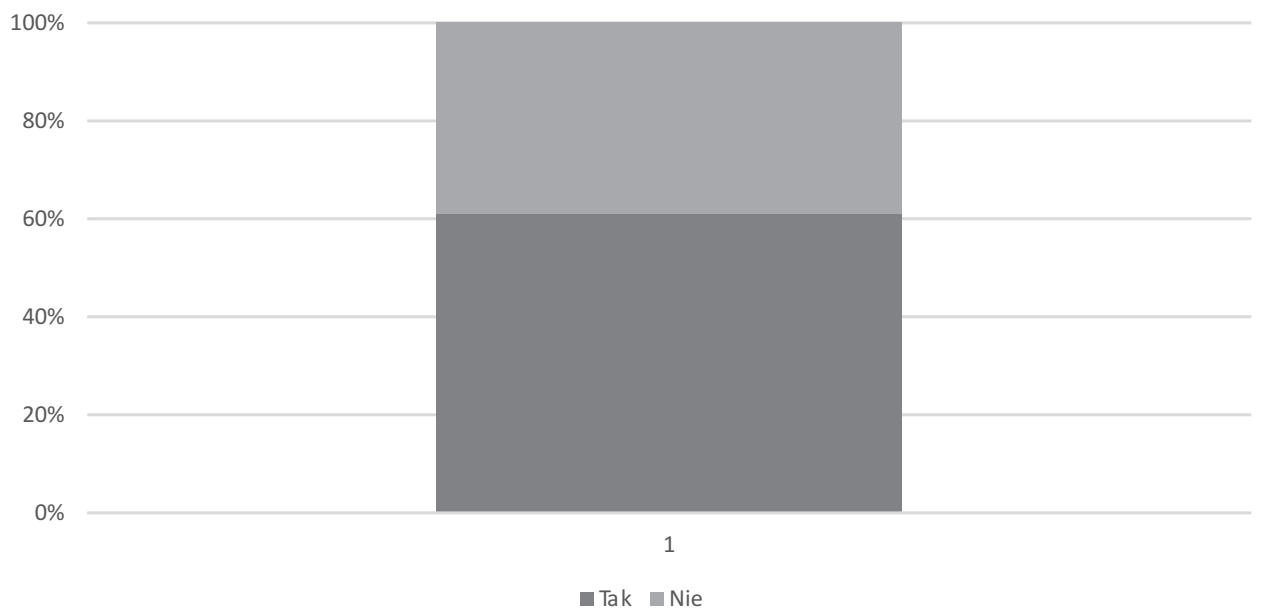

Ryc. 11. Stopień realizacji zaproszeń na bezpłatne badania cytologiczne $(\mathrm{N}=185)$

Źr ódło: Wyniki projektu 
Wśród przyczyn niezgłoszenia najczęściej wymieniano fakt, że badanie cytologiczne zostało już zrealizowane wcześniej, niezależnie od otrzymanego zaproszenia (38\%). Pozostałymi przyczynami niskiej zgłaszalności były: brak potrzeby poddania się badaniu (22\%), brak czasu i chęci (po 18\%) oraz zapomnienie (14\%) (ryc. 12).

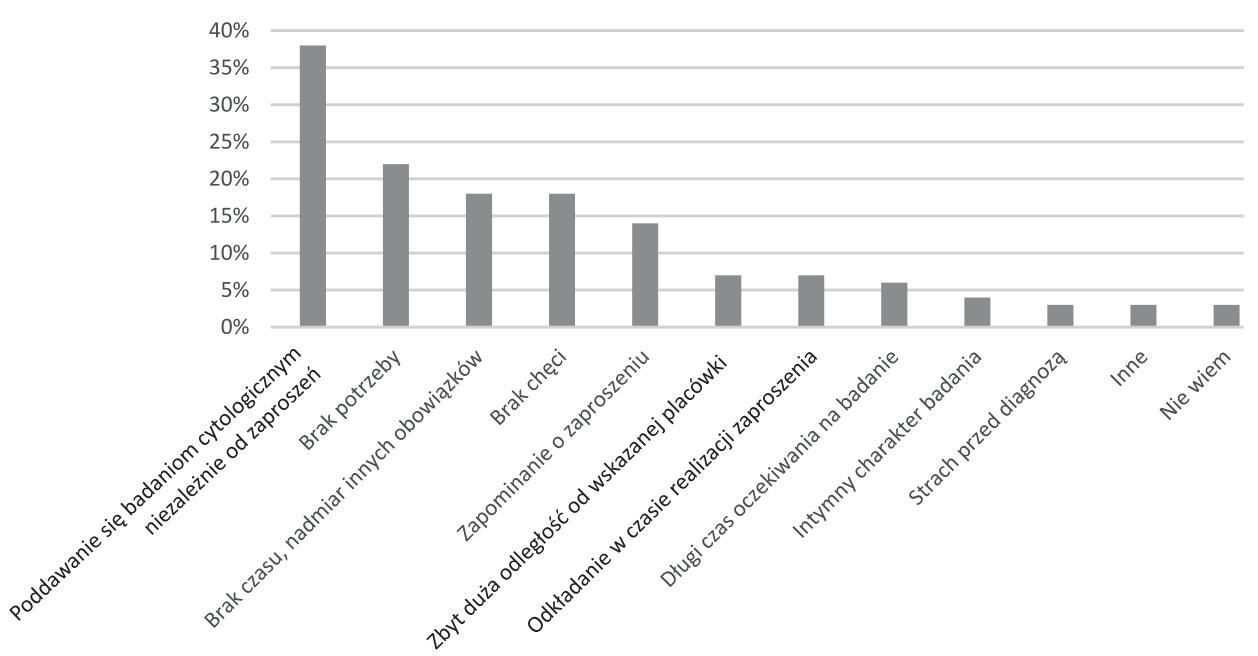

Ryc. 12. Przyczyny niezgłoszenia się na bezpłatne badanie cytologiczne w opinii badanych (analiza ilościowa: $\mathrm{N}=72$, max. 3)

\section{Źr ódło: Wyniki projektu}

Niezbędnym uzupełnieniem diagnozy przyczyn niskiej zgłaszalności na badania cytologiczne są wyniki analizy jakościowej 80 wywiadów swobodnych, przeprowadzonych na pierwszym etapie projektu (ryc. 13). Pozwoliły one na wyłonienie innych aspektów wpływających na unikanie regularnych badań profilaktycznych, które w kontekście rekonstrukcji biografii respondentek mogą prowadzić do głębszego zrozumienia zjawiska abnegacji zdrowotnej. Na szczególną uwagę zasługuje kwestia jakości relacji lekarz-pacjent. Stworzenie atmosfery komfortu i bezpieczeństwa oraz wysoki poziom umiejętności interpersonalnych lekarza (przejawiający się w sposobie komunikacji i zindywidualizowanym podejściu do pacjentki) stanowiły czynniki wzmacniające pozytywne wzorce zachowań profilaktycznych.

Niestety, wyniki badań jakościowych przyniosły wiele przykładów stanowiących zaprzeczenie powyższego modelu, o czym świadczyły bogate w szczegóły opisy sytuacji, w których pacjentki zostały potraktowane w sposób niekulturalny, z brakiem poszanowania ich prawa do intymności czy informacji. Odmienny wątek stanowiło zagadnienie ograniczonego dostępu do bezpłatnych badań kobiet młodszych oraz (w szczególności) starszych niż zakładana grupa określona w PPPiWWSM, które wykazywały głębsze zainteresowanie profilaktyką, jednak relacjonowały trudności/brak wsparcia ze strony lekarza ginekologa. 

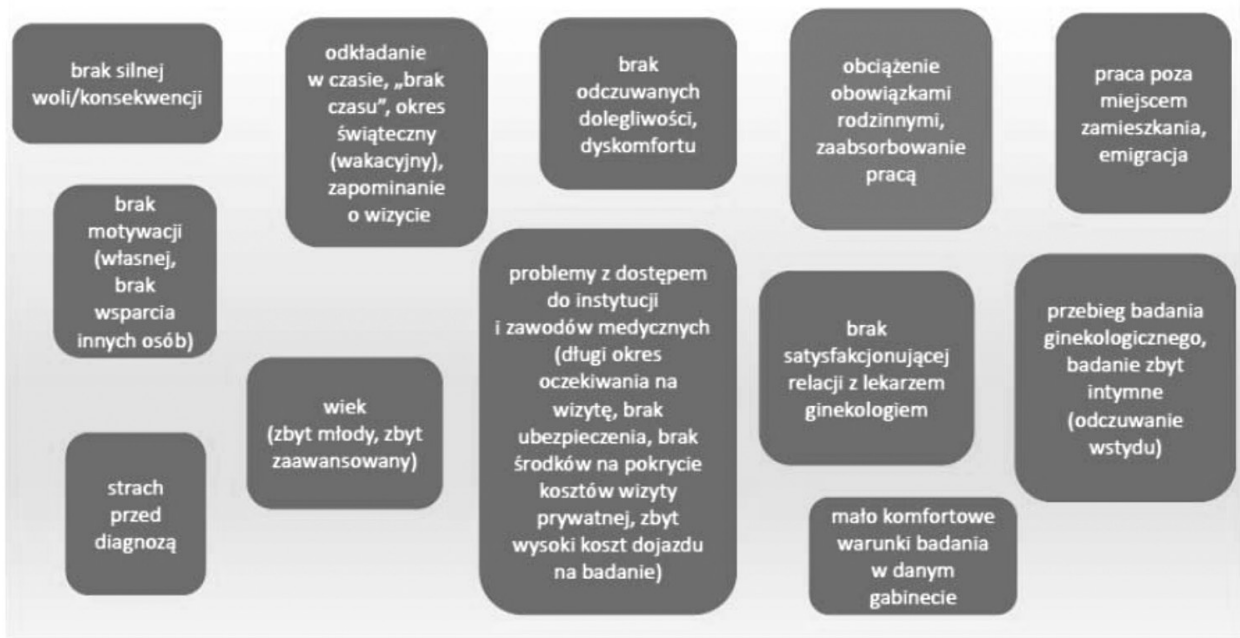

Ryc. 13. Przyczyny niezgłoszenia się na bezpłatne badanie cytologiczne w opinii badanych (analiza jakościowa: 80 wywiadów swobodnych)

\section{Źródło: Wyniki projektu}

Analiza jakościowa pozwoliła także na wyłonienie hipotez, które zostały zweryfikowane pozytywnie w świetle wyników badań ilościowych. Dotyczą one związków pomiędzy kapitałem społecznym kobiet a regularnym korzystaniem z opieki ginekologicznej, badań cytologicznych oraz zaproszeń na takie badania. $\mathrm{W}$ badaniach stwierdzono, że utrwalony nawyk korzystania z opieki ginekologicznej jeszcze przed zajściem w ciążę ma związek $\mathrm{z}$ regularnym poddawaniem się w latach późniejszych badaniom ginekologicznym (test chi-kwadrat: 48,553; $\mathrm{p}=0,000$ ), cytologicznym (test chi-kwadrat: 28,$867 ; \mathrm{p}=0,000$ ) oraz korzystaniem z zaproszeń oferowanych $\mathrm{w}$ ramach PPPiWWRSM (test chi-kwadrat: $6,011 ; p=0,014)$. „Wsparcie informacyjne” ze strony matki, dotyczące dbałości o zdrowie, pozytywnie przekładało się na regularność badań cytologicznych (test chi-kwadrat: 19,810; $\mathrm{p}=0,003$ ) i ginekologicznych (test chi-kwadrat: 19,230; $\mathrm{p}=0,002)$. Podobne zależności obserwowano $\mathrm{w}$ związku ze wsparciem ze strony męża/partnera (odpowiednio: test chi-kwadrat: $52,165, \mathrm{p}=0,000$; test chi-kwadrat: $67,530, p=0,000)$. Na większą regularność wizyt u lekarza ginekologa miały także wpływ prozdrowotne wzorce zachowań kobiet w otoczeniu społecznym respondentek (test chi-kwadrat: 55,369; $\mathrm{p}=0,000$ ). Zaobserwowane zależności przedstawiono na ryc. 14 . 


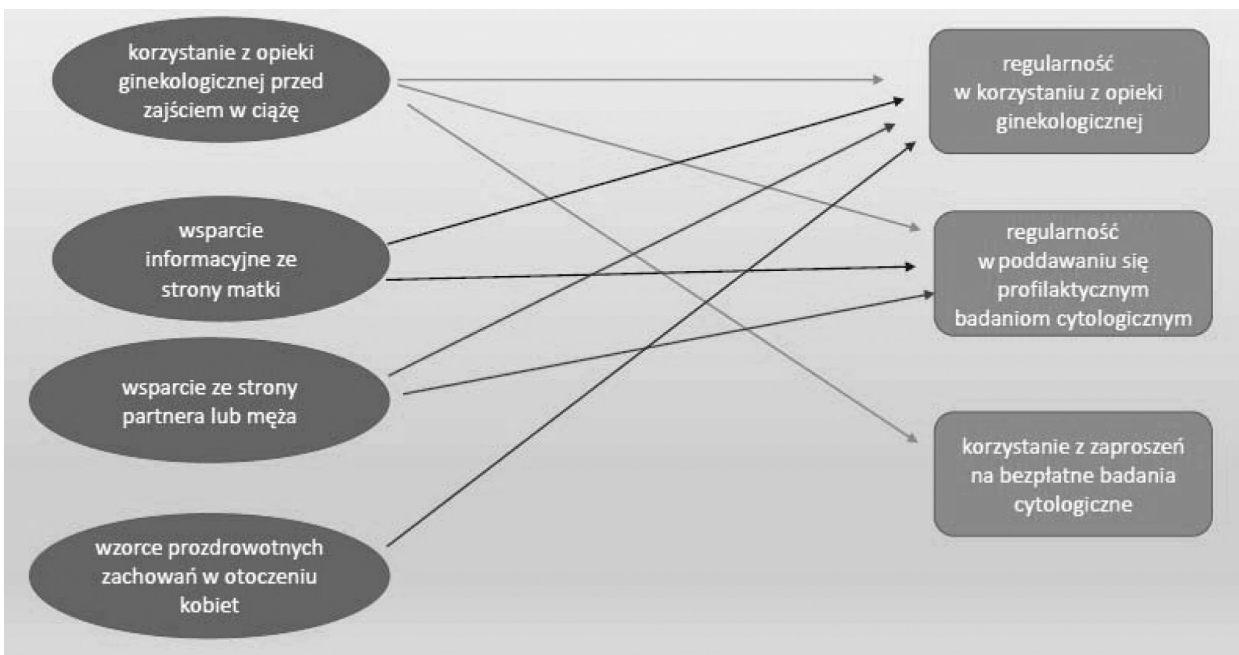

Ryc. 14. Znaczenie kapitału społecznego i jego wpływ na profilaktykę ginekologiczną

Źr ódło: Wyniki projektu

\section{Nierówności w zdrowiu a efektywność populacyjnych programów profilaktycznych}

Społeczny kontekst profilaktyki cytologicznej był przedmiotem zainteresowania socjologów od początku wdrożenia PPPiWWRSM. Na temat założeń tego projektu pisano: „Kompromisową opinię wyraził prof. Marek Spaczyński. [...] Podkreślił on, iż prowadzenie skriningu cytologicznego w Polsce należy utrzymywać w dotychczasowej formie, dążąc do stałego zwiększania jego efektywności poprzez konsekwentne podnoszenie wiedzy i świadomości naszego społeczeństwa" (Kempińska-Mirosławska 2012: 218). Socjologowie medycyny podkreślali, że z „behawioralnego punktu widzenia” istotny jest fakt, że Polska należy do krajów o najwyższych w Europie wskaźnikach umieralności na raka szyjki macicy i że dążenie do obniżenia wskaźników zapadalności i umieralności na ten nowotwór musi się wiązać z czynnikami o charakterze społecznym i kulturowym (świadomość zdrowotna, odczuwanie potrzeb w zakresie profilaktyki, podejmowanie prozdrowotnych zachowań etc.). Dodatkowym argumentem na rzecz wykorzystywania do celów prewencji znajomości praw społecznych było istnienie powszechnie od lat akceptowanej prawidłowości, że wczesne rozpoznanie nowotworu zwielokrotnia szanse skutecznego leczenia (O s tro w s k a 2011: 73).

Zdaniem Antoniny Ostrowskiej, która w swoich badaniach podejmowała problem profilaktyki ginekologicznej, ograniczona skuteczność programów profilaktycznych była wynikiem pomijania niektórych czynników socjopsychologicznych, 
m.in. niedostosowania języka i treści przekazu „komunikatów medycznych” do poziomu rozumienia oraz interpretacji kobiet, charakteryzujących się niskim poziomem wykształcenia, a także skrótowego i schematycznego opisu czynników ryzyka raka szyjki macicy. Inny problem stanowiło systematyczne przedstawianie badania cytologicznego jako skutecznego sposobu eliminującego ryzyko wystąpienia nowotworu, gdy tymczasem jest ono jedynie elementem tzw. ,profilaktyki wtórnej" (O s tro w ska 2011: 75-77). W badaniach dowiedziono, że mimo stosunkowo dużej wiedzy na temat profilaktyki, respondentki nie realizują zachowań profilaktycznych. Przyczyn tego relatywizmu postaw upatrywano m.in. w czynnikach społeczno-kulturowych, ogólnie trudnej sytuacji życiowej, niskiej świadomości zdrowotnej oraz ograniczonej dostępności infrastruktury medycznej (Ostrowska 2011: 82). Cytowane wyniki skłaniają do pesymistycznej konkluzji, że nawet wysoki poziom uświadomienia w zakresie etiologii i profilaktyki raka szyjki macicy nie jest równoznaczny z podjęciem zachowań prozdrowotnych (w tym przypadku: $\mathrm{z}$ wykonaniem badania cytologicznego).

Niezmiennie podstawową kwestią jest w tym kontekście dyskusja nad źródłem „barier”, opóźniających lub uniemożliwiających sukces profilaktyki oraz analiza kwestii efektywności. Oba zagadnienia ujawniają się podczas interpretacji badań jakościowych. Analiza treści 135 polskich i zagranicznych kampanii społecznych, poświęconych profilaktyce onkologicznej ujawnia szereg kwestii, mających znaczenie praktyczne (S y n o w i e c-P iłat 2012a: 68-69). Okazuje się, że większość tego typu programów ukierunkowana jest na zdrowie kobiet $(52 \%$ - w tym 10\% dotyczyło raka szyjki macicy), zaś zdrowie mężczyzn jest przedmiotem wyłącznego zainteresowania jedynie $2 \%$ z nich, mimo że - jak wskazuje autorka - „odnotowuje się szybszy wzrost zachorowalności na nowotwory wśród mężczyzn" (S y n o w i e c - P i ł at 2012a: 68). Głównym celem zachodnich kampanii profilaktycznych z lat 2009-2012 była, jak się okazało, edukacja zdrowotna społeczeństwa, szczególnie w zakresie profilaktyki chorób nowotworowych (w tym - przekazywanie społecznie aprobowanych informacji na temat testów cytologicznych; $9 \%$ analizowanych akcji profilaktycznych miało na celu przedstawienie opisu najczęstszych symptomów, towarzyszących typowym nowotworom). Inne programy miały za zadanie przełamanie bariery wstydu, towarzyszącej nowotworom zlokalizowanym w miejscach intymnych (piersi, jądra, odbyt, obszary genitalne). W wyniku przeprowadzonej w latach 20092012 analizy treści stron www dowiedziono, że zagadnienie ogólnego stopnia efektywności programów prewencyjnych było rzadko dyskutowane, podobnie jak ocena wpływu na realne zmiany w zachowaniach zdrowotnych odbiorców. Tymczasem taka analiza mogłaby przyczynić się do zwiększenia skuteczności kolejnych programów, których cele zakładają zmianę postaw i zachowań społecznych (S y n ow i e c-Piłat 2012b: 99).

W efekcie przedstawionych badań sformułowano następujące wnioski praktyczne: optymalną grupą wiekową, do której powinny być kierowane programy 
oświaty zdrowotnej, są ludzie młodzi i w średnim wieku, należy radykalnie zwiększyć liczbę programów adresowanych wyłącznie do mężczyzn, w treści przekazów należy zdecydowanie unikać elementów „negatywnych” (wywołujących strach), równocześnie pożądane jest zastosowanie „technik pozytywnego wzmocnienia emocjonalnego", konieczna jest też „personifikacja sukcesu”, a więc pokazanie wizerunku konkretnych osób, które skutecznie radzą sobie z chorobą nowotworową i na skutek własnych racjonalnych zachowań mają szansę na odniesienie zwycięstwa nad chorobą. Szczególnie efektywnym sposobem kształtowania prozdrowotnych postaw są „techniki wpływu społecznego”, które zmierzają do upodmiotowienia jednostek objętych programem, a przez to do zwiększania ich zaangażowania i aktywności w sferze zdrowia. Programy profilaktyczne powinny nawiązywać także do tzw. „podejścia siedliskowego”, obejmującego systematycznymi działaniami prewencyjnymi najbliższe otoczenie jednostki (dom, zakład pracy, szkołę, środowisko miejsca zamieszkania itp.) (S y n o w i e c-P iła t 2012: 99).

Aspekty socjologiczno-psychologiczne zostały także dostrzeżone przez Zespół Koordynujący PPPiWWRSM. Po kilku latach realizacji programu ostatecznie uznano, że „imienne zaproszenia nie są [wyróżnienie aut.] skuteczną metodą zwiększenia zgłaszalności kobiet na badania cytologiczne" (S pa c zy ń ski i in. 2009: 838). Brak pełnej efektywności jest zwłaszcza widoczny w odniesieniu do grupy kobiet o niskim (lub relatywnie niskim) poziomie wykształcenia, dochodów, mieszkających na wsi lub w małych miasteczkach. Pamiętajmy, że tak charakteryzowana populacja stanowi znaczny odsetek całej ludności Polski, a osób o wskazanych, podobnych ,cechach stratyfikacyjnych” jest zdecydowanie więcej niż w krajach, gdzie wcześniejsze programy profilaktyki onkologicznej odniosły sukces (np. Finlandia). Pamiętajmy też, że Polska ma jedne z najwyższych w UE wskaźników nierówności w zdrowiu (S o w a 2011: 28-37). Uwzględniając powyższe uwarunkowania, dyskusje nad przyczynami niskiej zgłaszalności kobiet do Programu i tzw. charakterystyka barier wydają się szczególnie cenne (S p a c z yń s k i i in. 2009: 835). Należy dodać, że bardzo ważna jest tu socjopsychologiczna analiza zwłaszcza dwóch istotnych kategorii odmów: „brak czasu” (24\%) i „niechęć do badań” (15\%) (S pa c zy ń ski i in. 2009: 836). Warto przy tym zauważyć, że są one usytuowane „blisko siebie”, co wydaje się potwierdzać zasadę, że jeśli nie ma silnej motywacji do podjęcia konkretnych zachowań społecznych, najczęściej uciekamy się do wygodnej, „neutralnej” i pojemnej wymówki tego typu, pozwalającej uchylić się od realizacji wskazań medycznych. Metodologia socjologicznych badań sondażowych dostarcza w tym zakresie wielu przykładów oraz interpretacji. Mechanizmy charakteryzujące w tych badaniach bariery ograniczające udział osób zaproszonych do partycypacji w Programie mają zatem w większości charakter „,behawioralny”. Problemy te wymagają z pewnością dalszej pogłębionej interpretacji przedstawicieli nauk społecznych (w tym omówienia zasad „teorii wpływu społecznego"), a nie np. zmian w celu poprawienia 
„logistyki" Programu. Takie kategorie analizowane w naukach o zachowaniu, jak np. „strach”, „nieufność”, „brak przekonania o celowości udziału w Programie”, „wstyd", „uczucie skrępowania” wymagają dogłębnej i systematycznej interpretacji ekspertów z zakresu nauk społecznych i psychologii medycyny. Należy je odnieść, przede wszystkim, do osób, które najczęściej nie przystępowały do Programu, a więc do kobiet - mieszkanek wsi i małych miasteczek, o niskim poziomie wykształcenia i dochodów.

\section{Zakończenie}

Ponieważ dotychczasowe polskie programy profilaktyczne były konceptualizowane i realizowane wyłącznie przez lekarzy klinicystów, na podstawie wzorców kampanii, prowadzonych w wysoko rozwiniętych krajach zachodnich, brakuje rzetelnej diagnozy ich niepełnej skuteczności. Nie mogą przynieść sukcesu próby „mechanicznego” wzorowania się i przeniesienia do Polski metod profilaktycznych, skutecznie praktykowanych w krajach skandynawskich, bowiem bilans różnic kulturowych, strukturalnych, religijnych i ekonomicznych dominuje tu nad podobieństwami (C o c k e r h a m 2004: 351-352). Nie ulega wątpliwości, że profilaktyka ginekologiczna w Polsce stanowi ważny problem badawczy i społeczny, dlatego należy pogłębiać uzyskane wyniki poprzez prowadzenie kompleksowych badań, z udziałem ekspertów z zakresu nauk o zachowaniu (w tym socjologów), uwzględniających podejście ilościowe i jakościowe. Projekt „Problem zgłaszalności kobiet na badania cytologiczne w Polsce. Próba analizy socjomedycznej” stanowi wstęp do interdyscyplinarnej dyskusji nad problematyką profilaktyki ginekologicznej w Polsce.

\section{Bibliografia}

C o c k e r h a m W. C. (2004), Medical Sociology, 9th ed., Pearson, Upper Saddle River.

Daykin N., N a id oo J. (2005), Feminist Critiques of Health Promotion, [w:] R. B u n to n, S. N e t $\mathrm{t} l$ e t o n, B u r r o w s R. (eds.), The Sociology of Health Promotion. Critical Analyses of Consumption, Lifestyle and Risk, Routledge, London-New York-Paris.

E ste s C. L., L in k in s K. W. (2000), Critical Perspective in Health and Aging, [w:] G. L. A 1bre cht, R. Fitzpatri ck, S. C. S crim s haw (eds.), The Handbook of Social Sciences and Medicine, Sage Publications, London.

K e m p i ń s k a - M i ro sła w s k B. (2012), Szczepionka na raka szyjki macicy-skuteczna profilaktyka czy płonne nadzieje na fali medialnego szumu?, [w:] M. G a ł u s z k a, M. W i e c z o r k o w s k a (red.), Społeczne, kulturowe i polityczne uwarunkowania ryzyka zdrowotnego, Wydawnictwo Uniwersytetu Medycznego w Łodzi, Łódź, s. 211-237.

M u $\mathrm{m}$ for d E. (1983), Medical Sociology. Patients, Providers and Policies, Random House, New York. N e t t 1 e t o n S. (2009), The Sociology of Health and Illness, 2nd ed., Polity Press, Cambridge.

Ostrowska A. (2011), Profilaktyka zdrowotna: interpretacje, definicje sytuacji, racjonalności (przypadek profilaktyki ginekologicznej kobiet), „Studia Socjologiczne”, nr 3 (202), s. 73-94. 
S ow a A. (2011), Społeczne uwarunkowania stanu zdrowia w Polsce, „Zdrowie Publiczne i Zarządzanie", T. IX, nr 2, s. 28-37.

S paczyński M., Nowak-Markwitz E., Januszek-Mi chalecka L., Karowi cz- B i 1 ińs k a A. (2009), Profil socjalny kobiet $i$ ich udziat w Programie Profilaktyki $i$ Wczesnego Wykrywania Raka Szyjki Macicy w Polsce, „Ginekologia Polska”, nr 80, s. 833-838.

S yn ow i e c-Piłat M. (2012a), Kampanie społeczne na rzecz pacjentów onkologicznych i ich najbliższych. Główne obszary działania, [w:] M. S y n o w i e c-P iłat, A. O lch ow s k a - K o t a la (red.), Socjologia i psychologia dla pacjenta - wybrane zagadnienia, Wydawnictwo Adam Marszałek, Toruń, s. 66-83.

S yn ow i e - P iłat M. (2012b), Realizacja idei upodmiotowienia na rzecz zdrowia w kampaniach społecznych dotyczacych problematyki onkologicznej, [w:] M. S y n o w i e c-P iła t, A. O $1 \mathrm{c}$ h ow s k a - K o ta 1 a (red.), Socjologia i psychologia dla pacjenta-wybrane zagadnienia, Wydawnictwo Adam Marszałek, Toruń, s. 84-105.

Włodzimierz Piątkowski, Anna Sadowska, Marcin Stanisław Bobiński, Wiesława Bednarek

\section{INEQUALITIES IN HEALTH IN LIGHT OF THE RESULTS OF PROJECT "THE PROBLEM OF ATTENDANCE OF WOMEN TO CYTOLOGICAL TESTS IN POLAND. A SOCIOMEDICAL ANALYSIS"}

Summary. Low attendance of women to free cytology tests under the Population Program of Prevention and Early Detection of Cervical Cancer (PPPWWRSM) is an issue that requires an in-depth analysis. The presented project is one of the first representative sociological inquiries concerning this subject. The main goal of the project was to describe and interpret the attitude of women towards preventive smear tests and the diagnosis of the reasons for avoidance/postponement in time of such tests.

Because of the complexity of the object of research two kinds of analysis were employed: qualitative and quantitative. 80 free interviews were conducted, the conclusions having been used at the stage of preparing the instrument for quantitative research. Personal interviews (CAPI) were conducted in the autumn of 2014 on the nationwide representative sample of 500 women aged 25-59 years (the population covered by the PPPWWRSM).

The result of research is the knowledge about the health behaviors of Polish women and their social determinants. Especially worth noting are different behavior patterns resulting from social-cultural diversity (inter alia age, place of residence, education), which manifest themselves in the use of gynecological care, knowledge about prevention and its sources, and in motivation for undertaking pro-health activities.

Keywords: social inequalities, gynaecological prophylaxis, medical sociology. 